NBER WORKING PAPER SERIES

DECODING MICROSOFT:
INTANGIBLE CAPITAL AS A SOURCE OF COMPANY GROWTH

Charles R. Hulten

Working Paper 15799

http://www.nber.org/papers/w15799

\author{
NATIONAL BUREAU OF ECONOMIC RESEARCH \\ 1050 Massachusetts Avenue \\ Cambridge, MA 02138 \\ March 2010
}

The research reported in this paper was sponsored by the Economics Program of The Conference Board as part of its Program on Intangibles. Their financial support is gratefully acknowledged. Many thanks are also due to Kathleen Miller for her valuable research assistance, and to Janet Hao for her help with the data. Thanks are also due to the participants at the 2009 NBER Summer Institute and subsequent seminars at which preliminary drafts were presented. Any opinions and interpretations, as well as errors, are solely my responsibility and should not be attributed to any organization with which I am affiliated.

NBER working papers are circulated for discussion and comment purposes. They have not been peerreviewed or been subject to the review by the NBER Board of Directors that accompanies official NBER publications.

(C) 2010 by Charles R. Hulten. All rights reserved. Short sections of text, not to exceed two paragraphs, may be quoted without explicit permission provided that full credit, including $\odot$ notice, is given to the source. 
Decoding Microsoft: Intangible Capital as a Source of Company Growth

Charles R. Hulten

NBER Working Paper No. 15799

March 2010

JEL No. O32,O47

\begin{abstract}
$\underline{\text { ABSTRACT }}$
A great deal of research has been devoted to the effects of technical change on economic growth. Less attention has been given to the factors driving the growth of the technological innovators themselves. This paper examines the case of one of the central contributors to the IT revolution, the Microsoft Corporation. The company's sources of growth are estimated using the conventional Solow-JorgensonGriliches "residual" model, expanded to include investments in product research and development, sales and marketing, and organizational development (collectively termed the company's "intangible" capital). The picture of Microsoft that emerges from this analysis is a story about the successful use of knowledge inputs to produce knowledge outputs. It is also a story of the importance of product innovation, rather than process innovation, as a source of total factor productivity growth. The theoretical underpinnings of the empirical analysis are also examined, and a model is sketched in which the neoclassical growth accounting framework is linked to the theoretically messier world of the Schumpeterian competitor via the Berndt-Fuss theorem on capital utilization.
\end{abstract}

Charles R. Hulten

Department of Economics

University of Maryland

Room 3105, Tydings Hall

College Park, MD 20742

and NBER

hulten@econ.umd.edu 


\section{DECODING MICROSOFT: \\ INTANGIBLE CAPITAL AS A SOURCE OF COMPANY GROWTH}

The revolution in information technology emerged in full force in the 1980s, with the advent of personal computers, mobile cellular telephones, followed somewhat later by the internet and a host of other IT products. The revolution was based on advances in technical knowledge, augmented by creativity and luck, and it involved the expenditure of considerable resources. Many companies entered the IT tournament, but only a few emerged with the prizes.

The Microsoft Corporation was one of the fundamental contributors to the IT revolution, and one of the principal winners. Microsoft began its life as a publicly-traded company in 1986 and has grown to dominate the market for computer operating systems and office application suites. Revenues grew from \$198 million in 1986 to $\$ 44,282$ million in 2006 , and the stock price increased from its offering value of $\$ 21$ per share (about $\$ 0.08$ when adjusted for stock splits) to a peak of around $\$ 50$ in late 1999 (again, split adjusted), and is now around $\$ 28$.

This remarkable growth parallels the similarly phenomenal growth of information technology itself. Business investment expenditures for software grew from $\$ 26$ billion in 1986 to $\$ 227$ billion in 2007 , while computer investment grew from $\$ 34$ to $\$ 94$ billion over the same period. Microsoft was at the center of this growth story, riding the wave of demand for software created by the structural shift toward IT. However, there is more to the Microsoft story than the surge in demand for software. This paper examines the "supply" side drivers of Microsoft's growth, using the same general sources-of-growth approach the Bureau of Labor Statistics (BLS) uses for its macroeconomic productivity estimates. But, unlike the BLS approach, this research follows Corrado, Hulten and 
Sichel (CHS, 2009) in adding the investment in intangibles to the list of inputs and outputs. ${ }^{1}$ The list of intangibles includes product research and development, sales and marketing, finance and management, all of which provide the intellectual-property infrastructure of a company like Microsoft.

The main data used to estimate the sources of Microsoft's growth are obtained from the company's publicly available financial reports. These data are reported in the current dollars of each year, and need to be converted to inflation-adjusted ('real') prices to be useful for growth analysis. The company's own-account intangible assets must also be estimated, since current accounting practice does not include this category of capital on the firm's balance sheet. Finally, the estimates must be put into a sources-ofgrowth format.

The main result emerging from the analysis is that the company has a lot more capital than is apparent from its financial statements. Conventional accounting practice puts Microsoft's balance sheet assets at some $\$ 70$ billion in 2006, but the estimates of this paper reveal an additional $\$ 66$ billion in missing intangible capital. These additional assets cause shareholder equity to jump from $\$ 40$ billion to $\$ 106$ billion. When the additional equity is counted, the rate of return to equity investors is found to be dramatically lower, falling from the conventional rate of 31.4 percent to an intangiblescorrected 15.7 percent.

\footnotetext{
1 The analysis of Microsoft's growth in this study is largely empirical. However, theoretical issues cannot be avoided. The sources-of-growth model used in this paper presumes perfectly competitive markets, little uncertainty about the outcome of investments, and is strongly oriented to the actual making of goods and services. None of these assumptions fit the case of Microsoft, which operates more like a Schumpeterian competitor in a world of uncertainty and product competition. One objective of this paper is to sketch a version of the Schumpeterian growth framework that is appropriate for Microsoft, but which can be linked back to the sources-of-growth model.
} 
The "missing" intangible capital is also important for understanding the rapid growth of Microsoft's real output. The company grew at a healthy average annual rate of 30 percent over the period 1988 to 2006 , driven by rates total factor productivity (TFP) growth and capital formation that greatly exceed those of the nonfarm business sector as a whole. Intangible capital accounted for more than 40 percent of Microsoft's growth, while the next largest source of growth, TFP, accounted for just 20 percent. Within TFP, only about a fifth of this 20 percent increase was due to improvements in the efficiency of the production process (the usual interpretation of TFP), while the rest was due to improvements in the quality of Microsoft's output. Investment in IT equipment was of negligible importance. The story of Microsoft that emerges from this analysis is a story about intangible intellectual capital and, in particular, about the successful use of 'knowledge' inputs to produce 'knowledge' outputs.

\section{Macroeconomic Growth and the IT Revolution}

The ability of an economy to grow its real GDP depends on how successful it is in growing the inputs of capital and labor needed to produce the product, and on its ability to increase the productivity of those inputs. Economists have studied this process using a variety of techniques, but the one that has gained the greatest traction is the "sources-of-growth" model developed by Robert Solow (1957), Dale Jorgenson and Zvi Griliches (1967), and others. ${ }^{2}$ This is the model used by the BLS in its productivity program, and by the OECD. The basic idea is to assume that there is a

\footnotetext{
2 The development of this model is surveyed in the recent article by Hulten (2009). A large body of research has evolved from these early contributions, as represented by the recent research by van Ark et. al. (2008) on the growth of European economies.
} 
stable link between input and output (the production function) and to use this link to divide the growth rate of output between (1) the growth rates of a list of inputs (capital and labor in the macro economy), each weighted by its relative contribution to output, and (2) an unexplained residual which is interpreted as the change in the joint productivity with which the inputs are used (TFP).

Table 1 shows the BLS estimates for the non-farm business economy of the U.S. over the years 1973 to $2003 .{ }^{3}$ These estimates tell the story of the growth of this sector and highlight the roles played by IT-related inputs. In the high-growth period from 1995 to 2003 , IT and software were responsible for 34 percent of sectoral growth, and changes in labor composition toward more educated workers accounted for another 13 percent. Traditional 'bricks-and-mortar' capital, that is, plant and equipment, played only a minor role. The largest individual contributor to growth was TFP (45 percent), Because TFP is measured as a residual, it sweeps together many factors not directly related to technology, like variations in capacity utilization. However, over longer time intervals in technologically advanced countries, it captures the diffusion of technical knowledge and organizational know-how.

Table 1 also shows the productivity slowdown of the early 1970 s to the mid1990s and the pick-up in productivity that followed. The growth rate of output per worker nearly doubled between the two periods, driven by the change in TFP growth

\footnotetext{
${ }^{3}$ Following the BLS convention, the growth of output and capital is shown in this figure in per worker terms. This is essentially the same growth accounting story as when output and capital are represented alone. When the focus is on individual companies, as later in this paper, the latter framework is preferable, because it more naturally represents the role of other inputs like materials, energy, and purchased services.
} 
(57 percent of the pick-up) and the growth in IT and software (36 percent of the pickup).

There is, however, something missing from this picture. In the cover story of BusinessWeek in February 2006, Michael Mandel observed:

"Grab your iPod, flip it over, and read the script at the bottom. It says: 'Designed by Apple in California. Assembled in China.' Where the gizmo is made is immaterial to its popularity. It is great design, technical innovation, and savvy marketing that have helped Apple Computer sell more than $\mathbf{4 0}$ million iPods. Yet the [U.S. national accounts doesn't] count what Apple spends on R\&D and brand development, which totaled at least $\$ 800$ million in 2005."

The same observation applies to Microsoft keyboards ("Designed in Redmond, WA USA ... Made in China"). The "great design" and "savvy marketing" are not in the BLS productivity numbers, nor, until recently, are they in the GDP estimates. ${ }^{4}$ They are, however, as much a part of the 'knowledge revolution' as computers and software, and, they are important. Estimates by Nakamura (2001) and Corrado, Hulten, and Sichel (2005) suggest that U.S. businesses invest as much in their intangibles as they do in their plant and equipment (including IT). CHS put the amount of 'missing' intangible investment at more than $\$ 1$ trillion in the early 2000 s, and the corresponding amount of intangible capital at $\$ 3.4$ trillion.

What exactly are these intangibles assets? In the CHS studies, they include R\&D, both scientific and non-scientific, software, worker-training, brand equity, and organizational development. They do not affect the current volume of output produced, and differ, in this regard, from tangible plant and equipment. Instead, they typically

\footnotetext{
${ }^{4}$ Mandel's comment refers specifically to the U.S. national accounts produced by the Bureau of Economic Analysis (BEA), but applies with equal force to financial accounting practice. BEA has recently moved to capitalize R\&D (Robbins and Moylan (2007)), but financial accounts still omit most of the intangible capital produced within a company.
} 
involve the development of specific products or processes, or are investments in organizational capabilities, creating or strengthening product platforms that position a firm to compete in certain markets (and, they may be play both roles simultaneously). Intangibles frequently involve the development and use of knowledge (technology, organizational know-how, business models) and are therefore "non-rival," in the sense they can often be used by more than one firm (the source of appropriability problems) or have multiple uses over time by the same firm (one source of cost allocation problems). They are predominantly developed within the firm that is the primary user, and they form the intellectual-property of the firm. Finally, they are called "intangibles" because that is, in fact, what they are. They lack a physical embodiment like other inputs, and are therefore not directly visible like buildings and equipment. The latter can be enumerated and their age and condition assessed, but in what units do you measure knowledge or expertise, and how do you know when intangibles are no longer in use? This lack of visibility is one of the reasons that they are excluded from financial accounts, and it is the source of skepticism about their status as capital. ${ }^{5}$

Outlays for business intangibles have increased sharply over time. At the 2000 peak, intangible investments claimed about 10 percent of non-farm business revenues, up from 2 percent five decades earlier. The trend in the corresponding share of tangible investments was almost flat at around 12 percent. There was thus a shift in the

\footnotetext{
${ }^{5}$ It is fairly clear that R\&D is more oriented to future products and processes than to current ones, but there is less of a consensus that sales and marketing, as well as organizational competency, should be treated as capital. After all, much advertising is transitory (the Sunday adds, etc.). However, marketing is much more than advertising. According to Microsoft's 2006 Form 10k report, advertising expenses were only 12.5 percent of total sales and marketing expenses. And, even advertising contributes to branding equity. Moreover, it is clear from IBM's Emerging Business Opportunity program that product development is the result of an interaction between technological capability, market analysis and customer interaction, and product design (see Garvin and Levesque (2006)). A product may be technologically feasible, indeed, brilliantly novel, but it has no economic value unless people know about it and want to buy it.
} 
composition of investment toward intangible assets that is absent from the growth estimates of Table 1.

Corrado, Hulten, and Sichel (2009) were the first to incorporate a broad list of intangibles into the BLS framework. First, some fraction of the total expenditure on intangibles were treated as an investment rather than as a current expense and added to GDP (the $\$ 1$ trillion noted above). Then, the $\$ 3.4$ trillion in additional capital stock was added to the input side of the national wealth account. With these additions, shown in Table 2, intangibles (including software) now account for 27 percent of the growth in output in the period after 1995. Furthermore, when the growth in IT equipment is added to this 27 percent, along with the education-driven labor composition term, informationbased inputs account for 57 percent of output growth. This figure might be even larger, because some fraction of TFP growth is due to technology spillovers (the BLS puts this figure at 23 percent for the period 2000-2007, for scientific R\&D alone). In any event, technology/knowledge in its many manifestations appears to be the dominant force driving recent business-sector growth trends.

\section{Microsoft's Intangible Capital}

The macroeconomic estimates suggest an important role for intangibles, both as a driver of economic growth and as a source of national wealth. It is therefore not surprising that they also appear as an important source of value and growth for the Microsoft Corporation. Data from the company's annual reports suggest that most of Microsoft's employees are engaged in non-production activities. In 2006, only 3 percent of Microsoft's 71,000 employees were listed under the category "manufacturing and 
distribution (M\&D)", while the rest were in the following categories: 28 percent in "product research and development (PR\&D)", 30 percent in "sales and marketing (S\&M)", 17 percent in "product support and consulting (PS\&C)", and 10 percent in "general and administration (G\&A)". In other words, 97 percent of the work force apparently was not engaged in direct production/distribution activities, with the presumption that many were engaged in activities intended to stimulate future revenues and profits through the production of intangible capital.

This presumption is strengthened by the cost data reported on Microsoft's 2006 income statement. The cost of revenue accounted for some 30 percent of the total current cost (including depreciation), a greater fraction than the employment share, but the intangible categories still dominate: 35 percent went to sales and marketing, 25 percent to product research and development, and the rest to general and administration. The last three non-production categories are, again, close to what the macro studies identify as being intangibles.

As in the CHS study, the capitalization of Microsoft's intangibles involves both an adjustment to the income statement and an expansion of the assets on the balance sheet. The first step is to decide what fraction of the reported intangible expenses, PR\&D, S\&M, and G\&A, are to be treated as capital investment. Following the general guidance of the CHS macro research, adjusted to reflect the high-technology nature of the company, the fractions selected were 100 percent (PR\&D), 70 percent (S\&M), and 20 percent (G\&A). The second step is to add a profit component to the current cost data to arrive at the full value of the investment. In this study, an imputed mark-up of $\$ 4$ billion is added to cost, based on a pro-rata cost share of Microsoft's overall net 
income. ${ }^{6}$ This is treated as an investment and added to the conventional measure of revenue of $\$ 44$ billion in 2006. Similar adjustments are made to S\&M and G\&A and after all are made, the value of product shown in Table 3 increases from $\$ 44$ billion to $\$ 67$ billion. $^{7}$

Once the investments in intangible capital have been estimated, they are added to the stocks of existing intangibles stocks built up from past investments, with a subtraction made for depreciation. The deprecation of the different types of capital is shown on line 9 of Table $3 .{ }^{8}$ The resulting net stocks of PR\&D, S\&M, and G\&A capital built up this way are shown in Table 4. The value of these stocks in 2006 was $\$ 66$ billion -- a value missing from the conventional balance sheet. These additional assets raise total assets to $\$ 136$ billion and shareholder equity to $\$ 106$ billion.

The depreciation from the newly-added intangible stocks affects adjusted net income. The additional $\$ 23$ billion in intangible investment added to the top line of Table 3 is partly offset by an additional $\$ 19$ billion depreciation charge, and, as a result, net income only increases by $\$ 4$ billion, from $\$ 13$ billion to $\$ 17$ billion. ${ }^{9}$ This $\$ 4$ billion is

\footnotetext{
6 The following thought experiment helps motivate this adjustment. Suppose that rather than producing PR\&D within the company, Microsoft were to outsource this function to another company. That company spends $\$ 7$ billion to produce the research that it then sells to Microsoft. The price charged to Microsoft would exceed the $\$ 7$ billion by the mark-up for profit that the research firm includes in its price. In this study, the markup is $\$ 4$ billion.

7 The $\$ 27$ billion cost of figure reported in Table 3 has been adjusted so as to subtract $\$ 1$ trillion in included depreciation of tangible capital. It is added back on the line that included the amortization of intangibles in the other columns).

8 The rates of depreciation used in this study are 25 percent for R\&D capital, 33 percent for S\&M, and 25 percent for G\&A. The corresponding dollar amounts in Table 3 are $\$ 9$ billion for R\&D, \$9 billion for S\&M, and $\$ 1$ billion for G\&A. The depreciation of tangible capital is shown as $\$ 1$ billion, though this was revalued to reflect Hulten-Wykoff depreciation rate for the productivity part of this research.
}

9 When a company's research budget is neither growing nor shrinking, the amount added to the top line as investment in R\&D just equals the amount of depreciation on the R\&D stock, leaving a zero balance. The increase in net income in Table 3 reflects the growth in Microsoft's intangible investment. 
the value to the shareholders of creating more intangible capital within the company than is lost to depreciation.

\section{The Sources of Company Value}

The addition of intangible capital to Microsoft's balance sheets suggests that Microsoft's shareholders have claim to a lot more capital than the books show -- $\$ 66$ billion more according to the estimates of this research. This is perhaps one factor explaining why the value of the company's shares, $\$ 238$ billion in 2006 , was much higher than the conventionally reported equity of $\$ 40$ billion. The additional $\$ 66$ billion in new intangibles narrows the market-to-book value gap significantly, from 17 percent to 45 percent. A study of 617 U.S. R\&D-oriented companies by Hulten and Hao (2008) found a narrowing of the gap from 31 percent to 75 percent in 2006.

The return to equity is also affected by extra intangible capital. The conventionally measured return on equity -- net income as a fraction of measured equity -- is 31.4 percent, but this falls to 15.7 percent under the new view when all the capital is counted. It is even lower, 12.3 percent, when the "cash-only" return on equity is considered. This is the return to the full capital base measured only with respect to the actual inflow of money from product sales, and it thus excludes the $\$ 4$ billion buildup of internal value because current investment in intangibles exceeds depreciation. By way of comparison with the 15.7 percent, Hulten and Hao (2008) found that the average return to equity in 2006 was 12.2 percent for their 617 company sample. ${ }^{10}$

\footnotetext{
10 These Hulten-Hao results are not exactly comparable to those for Microsoft in this paper because different assumptions about deprecation were used, as well as a different procedure for estimating the amount of S\&M and G\&A capital (Microsoft's financial reports provide unusually rich data on these intangibles and this permits more precise estimation procedures). In unpublished work with Janet Hao
} 


\section{The Sources of Microsoft's Growth}

The financial data shown in Tables 3 and 4 for 2006 provide the starting point for a growth analysis of the company. Similar tables can be constructed for the years 1986 to 2005 , using publicly available financial reports. These tables can then be aligned to form the time series required for the analysis. ${ }^{11}$ The resulting series are denominated either in the contemporary prices of each year, or, in the case of balance assets, in historical prices. ${ }^{12}$ These must be revalued in the prices of a common year in order to control for price inflation over time. Financial reports do not, however, provide the required price deflators, and they must therefore be approximated with deflators not specific to Microsoft. ${ }^{13}$ The exception is the price index for Microsoft software, which is used as the price of directly produced output, which is based on the Abel-Berndt-White

and Kirsten Jaeger using comparable assumptions, Microsoft's 2006 return on equity was found to be 14.5 percent, compared to 19.7 percent for Apple Computer, 12.3 percent for Cisco, 10.0 percent for Hewlett-Packard, 7.4 percent for Intel, 10.2 percent for IBM, and 15.8 percent for Oracle.

11 The alignment process is subject to some well-known caveats. The purpose of annual financial reports is to report the company's financial results and general condition for a given year. Changes in accounting rules and mergers and acquisitions can introduce inconsistencies with previous financial reports. The change in the treatment of employee stock options is a case in point. In this research, data has been adjusted for options to the extent possible, but the results have to be seen in light of these intertemporal consistency issues.

${ }^{12}$ Balance sheet tangibles are carried at their cost at the time of acquisition (historical cost), with possibly some subsequent revaluation. In this research, the $\$ 3$ billion in plant and equipment carried on Microsoft's books for 2006 is revalued to current prices (and depreciation is adjusted to reflect economic rather than accounting depreciation), giving a restated value of $\$ 6$ billion. The imputed value of the ownaccount intangibles is continuously revalued to current prices.

${ }^{13}$ For the three types of intangible capital, the following deflators were used: a BEA R\&D Price Deflator (R\&D), the BEA Advertising Output Price Index (S\&M), and the BLS wage index for executive, administrative, and managerial employees (G\&A). BLS investment price deflators were used for the various categories of tangible assets on the balance sheet, and the BLS intermediate input price deflator was used for that input. The wage rate was calculated implicitly from the annual employment at Microsoft in relation to an imputed labor-share data from the BLS. 
research on the price of Microsoft product, supplemented by the BEA prepackaged software deflator in those years no covered by ABW.

The average annual growth rates of inflation-corrected output and its components are shown in Table 5. Real revenue grew at an average annual rate of 32.9 percent over the period 1988 to 2006 , and total output (inclusive of own-account intangibles) grew at the slightly slower rate of 30.0 percent. $^{14}$ Growth in the early years was particularly high and has slowed as the company has matured. The middle panel shows that the share of revenue-generating output was stable at around 65 percent, and that the importance of R\&D investments shifts somewhat over time relative to sales and marketing. The bottom panel shows the growth rates of the price deflators for each type of output.

Table 6 presents the main results of the research: the drivers of Microsoft's output growth. The growth rate of output is allocated among the growth rates of the various inputs, each weighted by its share in the value of output, and what is left over is assigned to total factor productivity. ${ }^{15}$ Over the whole period of the analysis, the growth rate of output averaged 30.0 percent per year, and the growth in intangible capital accounted for 44 percent of this growth. The rest of the inputs explained another 35 percent, leaving 21 percent "explained" by the TFP residual. Intangibles were even

\footnotetext{
${ }^{14}$ The year 1988 is used as the starting point of the growth analysis rather than 1986 , in order to reduce the potential bias resulting from errors in the imputed values of the initial 1986 capital stocks.

15 If all the assumptions of Solow (1957) are met, the income share of each input represents the impact multiplier that the input has on output growth. (the "output elasticity") The unweighted stock of intangible capital grew at an average annual rate of 27.4 percent for the period 1988 to 2006 , and its average shareweight was 51.0 percent. The impact of intangible capital over the period was the product of the two, or 13.3 percent.
} 
more important over the most recent sub-period, 2001-2006, during which they explained 57 percent of output growth.

The relative contributions of the various types of tangible and intangible assets are shown at the bottom of Table 6 . R\&D and S\&M are roughly of equal importance for the period as a whole, but their importance has shifted somewhat over time toward R\&D. The contribution of IT capital is surprisingly small in all sub periods.

VI. Product versus Process Innovation Components of the TFP Residual

The standard view of the Solow TFP residual is that it represents a shift in a company's technology that makes existing inputs more productive. This view implicitly assumes that the change technology is driven by improvements in the processes of production. However, as Mandel pointed out, product innovation and marketing savvy are more important factors in the success of a technology company like Microsoft than the efficiency with which it, or others, make its products. How, then, is one to account for product innovation at a company like Microsoft? Where is it evident in the data? One answer is that it is built into the estimates of the intangibles in Table 6, but this is only a partial answer. Some part of TFP growth is driven by product innovation, via the way output prices are adjusted for improvements in product "quality".

This quality adjustment is implicit in the price estimates of Table 5. One of the notable features of this table is the sustained drop in the BEA prepackaged software price deflator, which declines at an average rate of 7.3 percent per year over the period 1988-2006. This decline reflects the adjustments made to the "raw" transaction price data in order to account for technical advances in Microsoft's software over time (the 
transition from DOS to Windows to XP; different generations of Word and Excel). This price decline occurs even though the transaction price of successive software packages may not have changed or may have risen. ${ }^{16}$ The rationale: as products get "better" relative to their predecessors, users get more capability per dollar spent. Adjustments must therefore be made to the price of new software to reflect the increase in capability, essentially converting "better" software into the equivalent "more" software.

One implication of this measurement convention is that the concept of output embodied in Tables 5 and 6 reflects quality as well as quantity growth. The relative magnitude of the two sources of growth can be estimated by comparing the "actual" output estimates of Tables 5 and 6 to an alternative estimate of output based on a "raw" software price deflator that shows no quality change (a counterfactual experiment roughly consistent with the data shown in Abel-Berndt-White). This comparison is made in Table 7, where the first two lines show growth in the actual software price (with the quality adjustment) and the zero-growth counterfactual. However, since software output is only around two-thirds of total product (intangible investment accounts for the rest), the price of "total output" falls at the lesser rate of -4.4 percent. The counterfactual price estimate, on the other hand, actually rises by 0.4 percent per year, not zero percent, because of net price increases in the intangible third of total output.

The shift in price concepts affects quantity of total output directly: if price were actually growing at 0.4 percent rather than falling at 4.4 percent, counterfactual total output must grow at a proportionately lower rate ( 4.8 percent) because the nominal

16 The BEA R\&D deflator, on the other hand, reflects productivity gains in the R\&D production function, with the result that there is essentially no net price change over the period of analysis. The other ownaccount intangibles show a steady rate of price increase. 
value of total output is not affected by the quality adjustment or its absence. This is shown on the fifth and sixth lines of Table 7.

How is the slower output growth under the counterfactual reflected in the sources-of-growth table? Since the input side of the analysis is not affected by the adjustment to output (input shares and input growth rates are the same), the entire change in output growth shows up as an equal change in TFP growth, which is lowered by the same 4.8 percent per year over the whole period (to an annual rate of 1.4 percent from 6.2 percent). The revised 1.4 percent rate of TFP growth can be loosely interpreted as process-oriented productivity change, that is, as an increase in the efficiency with which units of "raw" output (uncorrected for quality change) are made. The remaining 4.8 percent of TFP growth can be interpreted as the product-oriented technical change not accounted for by the inputs used to produce the quality change in total output -- in essence, productivity gains in the product development process.

\section{Micro-Macro Comparison}

A quick look at Tables 2 and 6 suggests that the Microsoft experience is not typical of the business sector as a whole. However, while these tables are constructed along similar lines, two further steps are needed to put the estimates on a common basis. First, the definitions of output must be made comparable. Microsoft's accounts include the costs of all the inputs used by the company, including the materials, energy, and purchased services (collectively, the "intermediate" inputs), and the associated output concept is therefore defined to be "gross" of these intermediate inputs. The estimates in Table 2, on the other hand, show the combined results of many 
businesses, some of which produce the intermediate goods and others that use them. As a result, the intermediate inputs and outputs cancel each other in the process of aggregation, leaving only the contributions of labor and capital ("value added") in business GDP. Microsoft's output must therefore be put on a value-added basis for purposes of comparison.

The estimates of Table 2 are also expressed on a per worker basis, and Microsoft's estimates must be adjusted accordingly. When these adjustments are made in Table 8, the resulting growth in real value-added per worker at Microsoft is found to have grown at a much higher average annual rate over the period 1995-2003 than in the nonfarm business sector as a whole, 10.0 percent compared to the 3.09 percent from Table 2. Intangibles per worker (excluding software) were a much more important source of growth at Microsoft, adding 6.3 percentage points (or 63 percent of the total), but only 0.57 percentage points for the business sector (18 percent of the total). On the other hand, Microsoft's "TFP" was relatively less important as a driver of growth (35 percent of company growth versus 46 for the sector as a whole), even though its TFP growth rate was actually larger in absolute terms (3.5 percent compared to 1.08 plus the labor composition effect 0.33 ). ${ }^{17}$ Only tangibles per worker (including software) were stronger in the business sector, accounting for 1.12 of growth versus Microsoft's 0.2 percent. In other words, Microsoft's growth and innovation statistics have far exceeded the average for the business sector and were more strongly oriented to intangibles.

\footnotetext{
17 There is no explicit labor-composition for term for Microsoft, and its effects are therefore suppressed into the TFP residual. Data constraints also cause software to be combined with computing equipment in tangible capital. The quotation marks around Microsoft's "TFP" are put there as a signal that this is not a true productivity measure, but one in which the true TFP residual (which is smaller) has been inflated by the share of intermediate inputs (see Hulten (2009) for more on this issue).
} 
Unfortunately, there is no counterpart in Tables 1 or 2 to the product-quality decomposition in Table 7. The output price deflators used in the former embody a certain amount of quality change from the way they are constructed, but the extent of these quality adjustments is unknown (National Research Council (2002)). Nordhaus (1997) suggests that it may be quite large.

\section{Schumpeter Versus Solow}

A deeper problem in linking micro and macro productivity estimates arises on the theory side of the analysis. The Solow-Jorgenson-Griliches neoclassical growth framework of Table 1 postulates a tight link between input and output at the macro level of economic activity. This is the aggregate production function. This model also assumes that product and input markets are perfectly competitive, and that companies have a high degree of foresight about the profitability of their investments and proceed to make investments up to the point that the discounted present value of expected returns equals the cost of the marginal investment (a standard feature of economic and finance theory). Underpinning this model at the microeconomic level is the "representative" firm, an Adam-Smith-like entity that obeys the laws of the marketplace and is disciplined by the Invisible Hand.

The neoclassical representative-firm parable is hard to accept as a model for a company like Microsoft. The modern innovator typically operates in a more complex economic environment than Adam Smith's perfect price competitor, the Schumpeterian tournament noted above. Unlike the representative firm model, the Schumpeterian process is dominated by technological competition and uncertainty, and the successful 
firms may win a large ex post return on the cost of their investments. Those firms that do not succeed exit the competition or wait for the next round in the technology tournament. This is the process of creative destruction. ${ }^{18}$

To analyze Microsoft is thus to analyze a non-representative firm in which costbased estimates of asset value are likely to underestimate the realized value of those investments. The comparison between Microsoft and the non-farm business sector as a whole in Table 8 should be interpreted with this fact in mind. However, it is a mistake to focus exclusively on the higher ex post rate of return. Many intangible investments are existential in nature, made in order to manage the variance in outcomes and not just to achieve some rate of return. These investments form an infrastructural platform that helps defend against the vicissitudes of the marketplace, and the link between the cost of building and maintaining the platform and specific future outcomes is complex. ${ }^{19}$ Viewed this way, intangible platforms define the company just as much as the other way around. $^{20}$

\footnotetext{
${ }^{18}$ In an early paper using the Census Longitudinal Research Database to study the dynamics of individual establishments, Baily, Hulten, and Campbell (1992) confronted the representative-firm and Schumpeterian models. They found that a high level of TFP persisted in those establishments that started the sample period with higher levels of TFP, implying that success (as measured by TFP) persisted far longer than implied by the representative-firm model, For more on the theory of Schumpeterian growth, see Aghion and Howitt $(1992,2007)$.

19 It is important to emphasize, in this regard, that the return to product research and development and marketing may not be derived exclusively from the sale of specific products. The technological expertise and marketing know-how acquired when developing one generation of a product adds to the knowledge infrastructure that enables the development of future generations of products or processes. For example, current research may yield results that shape the direction of future research and make it more productive, over and above enabling specific products and processes directly.

20 The recent award of the Nobel Prize in Economics to Oliver Williamson has refocused attention to a question originally raised by Ronald Coase: why do companies exist at all in a competitive marketplace, given that the Invisible Hand is the most efficient manager of all? Their general answer is that the existence of transaction costs makes it cheaper to manage certain activities within the boundaries of the firm. Intangible capital provides another, though not entirely competing, answer. It is no accident that most of the investment in intangibles is made within the firm, and that this investment accounts for more of the firm's market capitalization than its conventional equity (Hulten and Hao (2008)). Nor is it an
} 
The Schumpeterian view of Microsoft also has a direct implication for the interpretation of the numbers in Table 6 . In the neoclassical paradigm, the income share of each input is multiplied by the corresponding growth rate and interpreted as the net impact of that input's growth on the growth in output. For a successful technology company, the share of capital is likely to be larger than average (for Microsoft it is around 60 percent of total product value). The corresponding capital share in Table 2 for the nonfarm business sector is around 40 percent. Microsoft's larger capital share amplifies that input's importance. If this result is due to pricing power rather than productivity, the sources-of-growth estimates of Table 6 may be subject to the bias noted by Robert Hall in 1988.

A more general problem is that both the neoclassical competitive model of growth and the Hall monopolistic competition model are oriented to the production of goods and services, and involve a relation between marginal revenue from selling an extra unit and the marginal cost of producing the unit. But, when intangible capital is seen as the foundation of a company's success, the relation between price and cost is much more ambiguous. Intangible costs are fixed from the standpoint of production, and for a company like Microsoft, they dominate the cost structure (recall Table 3). Explaining how these non-production fixed costs affect the operation of the firm (as they must in the long run) requires a theory that is not limited to the production of goods.

The production-oriented sources-of-growth model would therefore appear to be an unpromising way to look at the Schumpeterian growth of an individual company. However, it turns out that the two perspectives can be bridged in a way that preserves (1992)). Again, proprietary intangibles provide the infrastructure that gives a company many of its distinctive features and helps sustain it once it becomes established in the marketplace. 
the empirical usefulness of the neoclassical model while preserving much of the Schumpeterian process that generates the company-level data. This bridge is constructed by reinterpreting a result from the neoclassical literature by Ernst Berndt and Melvyn Fuss in 1986, developed for the purpose of explaining variations in capital utilization.

\section{The Berndt-Fuss Bridge}

\section{A. The Berndt-Fuss Theorem with Tangible Capital}

The size of a company's plant and equipment is hard to vary in the short run, and this poses a fundamental problem for productivity analysis. Fluctuations in demand over the business cycle lead to changes in the quantity of the services from the stock. The sources-of-growth analysis would ideally track the fluctuations in the service flows, but cannot because only the stock can be readily measured. The disconnect between stock and flow measures of capital input introduces a bias into the analysis: as output declines during a recession, so do labor and intermediate inputs, but capital stock tends to fall much less sharply. The discrepancy between the stock and flow of capital services is suppressed into the TFP residual, which thus tends to be procyclical.

Bendt and Fuss provide an ingenious solution to this problem. They observe that the return to capital (not just TFP) is measured as a residual in the sources-of-growth analysis, following the procedure developed by Jorgenson and Griliches to insure that the identity between the value of output and input always holds. They show that the ex 
post residual return method embodies a correction for the bias due to variations in capital utilization, at least in the case where there is a single capital good. ${ }^{21}$

Figure 1 shows how the Berndt-Fuss theorem operates in cost space when an increase in demand raises the price of output. The firm operates under constant returns to scale in the long run, on its long-run average and marginal cost function (LRAC) and is in equilibrium at the point $A$, with price $P^{*}(t)$ and quantity $Q^{*}(t)$. Because capital is fixed in the short run, a short-run U-shaped average cost curve (SRAC) is tangent to the LRAC at the point A, and the short-run marginal cost curve cuts through the SRAC at this minimum point. An increase in demand raises the price to $P^{* *}(t)$, and the firm reacts by moving up its SRMC from $A$ to $B$, by increasing the amount of variable inputs applied to the fixed stock of capital. Output increases from $Q^{*}(t)$ to $Q^{* *}(t)$, and the firm earns an excess profit of $\left[P^{* *}(t)-A C(t)\right] Q^{* *}(t)$. This profit accrues to the fixed capital stock as a short-run quasi-rent, in addition to the normal return already embedded in the long-run cost structure.

Berndt and Fuss prove that the price of capital services inclusive of this extra return just matches the increase in the value of the marginal product of capital that occurs because more variable input has been applied to the fixed stock. This, in turn, implies that capital's share of income, inclusive of the short-run return, equals the capital's output elasticity at the quantity $Q^{* *}(t)$. By implication, the TFP residual is not

\footnotetext{
${ }^{21}$ When there is more than one type of capital good, the Berndt-Fuss result does not apply to each type of capital good separately. As noted in Hulten (2009), the result does hold approximately for the entire collection of capital goods, and exactly when the production function is separable into a capital subaggregate.
} 
biased because of the short-run fixity of the capital stock, and the usual procedures for computing the TFP residual can be used.

\section{B. Enter Intangible Capital}

Although intangible capital was not part of the Berndt-Fuss analysis, it has a natural interpretation in the Figure 1 framework, even though it is not a direct input to production. Like short-run tangible capital, intangible capital is fixed from the standpoint of production and, with a suitable reinterpretation, the fixed-cost analysis of the Figure 1 framework can be deployed. The key step in this process is to view a company like Microsoft as a three part organization. The first part is the operational segment, in which the company's goods and services are produced and distributed. This is the segment that generates the cash revenues that appear on the top line of the company's annual income statement. The second, or administrative segment, takes care of the day-to-day management of the company: the payrolls, accounting, facilities management, financial control, and so on. The final segment deals with the longer-term objectives and capabilities of the company, including research, product development and design, marketing and brand equity, and strategic planning. This is the company's strategic segment. It might also be called the Schumpeterian segment. ${ }^{22}$

The neoclassical theory of the firm deals almost exclusively with the operational segment. However, the non-production segments do have an indirect influence on the amount of output produced in any year even though they do not influence production

22 The data generated by these three segments are aggregated and reported on the company income statement. In Table 3, the results shown on lines 1 and 2 were generated largely by Microsoft's operating segment, while the R\&D on line 3 originated in the strategic segment. The results reported on line 4 and 5 are split between the administrative and strategic segments. 
directly. This influence operates through two separate channels. First, the administrative segment and part of the strategic segment affect the effectiveness of the firm's operation, lowering the long- and short-run production costs. At the same time, they are a fixed cost that must be supported by the revenues from the operational segment, and this raises the overall production average cost structure. Under textbook marginalist profit maximization, the firm should invest in process-improving methods and administration up to the point where marginal benefits just equal marginal costs. In practice, however, the true cost margin may be hard to identify for the reason given above (the platform nature of many intangible investments), and because of the uncertainty associated with the innovation process.

The strategic segment's second role is to influence the level of demand through product development and marketing. The larger the investment in PR\&D and S\&M, the stronger the expected demand in future periods, as portrayed in Figure 2 by two groups of demand curves. This figure is adapted from the textbook theory of advertising, in which advertising expenditures are treated as a fixed cost from the standpoint of production (see, for example, the treatment in Pindyck and Rubenfeld (2009)). This additional cost raises the overall average cost structure but also shifts the product demand curve outward.

The model sketched in Figure 2 builds on this approach, but demand is now stochastic and there is an ex ante distribution of demand curves associated with a given level of fixed cost. The right-hand diagram in Figure 2 portrays the case in which there is more upfront investment in PR\&D and S\&M, and thus more fixed cost, but also a stronger distribution of product demand (i.e., one that lies to the right of the first 
distribution). Another difference from the advertising model is that the fixed cost is not a current outlay, but is instead the annual user cost associated with the stock of intangible capital. Moreover, this stock also comprises more than just advertising brand equity, since it also includes product research and development, as well as general marketing and organizational capital. One implication is that product characteristics are not necessarily fixed, and the cost structures in Figure 2 may refer to products with similar, but not identical, designs and qualities.

Once the optimal production/cost structure has been determined, an ex post demand curve emerges from the ex ante distribution, and an unlucky outcome leads to a loss or a good draw to a profit. The extent of profit or loss depends on the nature of pricing strategy, which may reflect an attempt to equate marginal revenue and marginal cost despite the problems of determining a marginal cost, but may also reflect strategic considerations arising from the threat posed by potential competitors.

Two key points emerge from this analysis. First, the stocks of PR\&D and S\&M are determined endogenously by the product/cost strategy adopted. This means that the quantity of intangible input is linked to the quantity of output produced and sold, even though intangibles play no direct role in the actual production process. This justifies their presence in the sources-of-growth analysis.

Second, once the policy has been set, the fixed-cost intangibles are a residual claimant to profits and losses. By analogy to the Berndt-Fuss analysis, a neoclassical sources-of-growth analysis that weights the growth rates of intangibles assets with their ex post income shares will provide a valid explanation of company growth along the lines of the Solow-Jorgenson-Griliches model. 
There is undoubtedly some degree of monopolistic pricing bias associated with favorable demand outcomes that persist over time (as in Hall (1988)). However, this bias may be attenuated by the uncertainties and cost allocation problems already noted. The dynamics of the Schumpeterian world are a lot more complicated than the stylized version presented in this section, and the cost and demand curves in Figure 2.

An exact mathematical model of this process is hard to construct, given the uncertain, non-rival, and possibly discontinuous ("lumpy") nature of some intangibles. ${ }^{23}$ One way to proceed is to ignore these problems and work with a restricted profit function, but there is still the difficult job of modeling the link between product development and marketing, on the one hand, and the distribution of demand curves, on the other.

However, the larger point is that the messy world of the Schumpeterian competitor can be linked to the stylized world of the neoclassical growth model in a way

\footnotetext{
23 This is not to minimize the contributions of the technical literature linking R\&D to the growth in output via technical change cum TFP (Romer (1986), Romer (1990), Jones (1995), Barro (1999), and Aghion and Howitt (2007), and the references contained therein). This literature makes two important points that are relevant for this paper. First, the knowledge spillovers associated with R\&D affect output growth through the TFP component of the sources-of-growth model (Romer (1986), Barro (1999)). This paper deals only with the appropriable part of R\&D knowledge (and other intangibles), and makes no estimate of the fraction of the TFP residual associated with spillovers. Second, this literature stresses that much R\&D knowledge is the result of a systematic production effort, and that it requires inputs of capital and labor. This is certainly the approach followed in CHS and this paper.
}

However, several problems limit the empirical applicability of this literature. First, even though ideas are produced, the product is not added to output in these models, as they are here and in CHS. The absence of R\&D output from total output implicitly assumes that it is not commercially appropriable, but is instead diffused throughout the economy as a costless increase in productivity. But, then, why would a private company invest resources in R\&D whose costs cannot be recovered? Second, the literature tends to assume a stable link between R\&D inputs and knowledge outcomes. While this link may be probabilistic, it generally suggests that increases in R\&D spending will continuously generate more output. This may be an acceptable approximation for the macroeconomic economy as a whole (though: a cure for cancer? energy from nuclear fusion?), but it seems implausible for individual companies like Microsoft that face pure uncertainty and technical limits to innovation. Finally, these models generally involve parameters that are too complex to be handled by the non-parametric sources-of-growth model. The proposed use of the Berndt-Fuss result in this paper is a way of avoiding the complexity and assumptions of this literature while still making use of the sources-of-growth technique. 
that preserves the powerful empirical tools of the latter and gives the sources-of-growth estimates of Table 6 of this paper a meaningful interpretation.

\section{Conclusion}

It is perhaps fitting to end with the following comment by Robert Solow, taken from his 1987 Nobel Laureate address:

"... I would like to remind my colleagues and their readers that every piece of empirical economics rests on a substructure of background assumptions that are probably not quite true. For instance, these total-factor-productivity calculations require not only that market prices can serve as a rough-and-ready approximation of marginal products, but that aggregation does not hopelessly distort these relationships. Under those circumstances, robustness should be the supreme econometric virtue, and overinterpretation the endemic econometric vice. So I would be happy if you were to accept that [growth accounting results] point to a qualitative truth and give perhaps some guide to orders of magnitude."

This warning is even more appropriate when the sources-of-growth model is applied to an individual company like Microsoft. Still, there are qualitative insights to be gained from the effort. The evidence strongly suggests that intangible inputs and outputs are central to the story of Microsoft's phenomenal growth. A number of assumptions (better, informed guesses) about key variables have been made, and many may be wrong, but it is hard to imagine that they are so wrong, given the magnitudes of the estimates, as to overturn this basic conclusion. The direct evidence from Microsoft's employment data shows a heavy emphasis on product development and support as well as marketing. And, the size of the R\&D budget alone suggests that billions of dollars of capital value have gone uncounted by current financial accounting practice. It 
is hard to imagine a plausible counter-argument that assigns absolutely no dynamic role to the company's intangibles.

A second objective of this study has been to justify using the neoclassical sources-of-growth model, the standard empirical model of macroeconomic growth, to analyze the growth of a Schumpeterian competitor like Microsoft. A theory has been sketched in which intangibles appear as fixed costs from the standpoint of the production model, but which are in fact variable inputs to a more complex growth process that includes the ability to develop and sell output as well as produce it. The nature of Microsoft's intangibles also requires a distinction between product and process-oriented technical change, introduced in this study and in a recent survey of growth accounting (Hulten (2009)). This distinction is needed to account for the product-oriented competition of companies like Microsoft, and the size of the empirical estimates suggests that it is a distinction that should not be ignored. 


\section{REFERENCES}

Abel, Jaison R., Ernst R. Berndt, and Alan G. White, "Price Indexes for Microsoft's Personal Computer Software Products," in Hard-to-Measure Goods and Services: Essays in Honor of Zvi Griliches, Ernst R, Berndt and Charles R. Hulten, eds., Studies in Income and Wealth, Vol. 67. Chicago: The University of Chicago Press, 2007, 269289.

Aghion, Phillippe, and Peter Howitt, "A Model of Growth through Creative Destruction," Econometrica, 60, 1992, 323-351.

Aghion, Phillippe, and Peter Howitt, "Capital, Innovation, and Growth Accounting," Oxford Review of Economic Policy, 23, 1, 2007, 79-93.

Baily, Martin N., Charles R. Hulten, and David Campbell, "Productivity Dynamics in Manufacturing Plants," Brookings Papers on Economic Activity, Microeconomics, 1992, 187-249.

Barro, Robert J., "Notes on Growth Accounting," Journal of Economic Growth, 4, June 1999, 119-137.

Berndt, Ernest R. and Melvyn A. Fuss, "Productivity Measurement With Adjustments for Variations in Capacity Utilization, and Other Forms of Temporary Equilibrium," Journal of Econometrics, 33, 1986, 7-29.

Brynjolfsson, Erik., and Lorin M. Hitt, "Remarks," In Measuring Capital in the New Economy, C. Corrado, J. Haltiwanger, and D. Sichel, eds., Studies in Income and Wealth, Vol. 65. Chicago: The University of Chicago Press, 2005, 567-575.

Coase, Ronald, "The Problem of Social Cost, Journal of Law and Economics, 3, October 1960, 1-44.

Coase, Ronald,"The Nature of the Firm," Economica, 4, 16, November 1937, 386-405.

Corrado, Carol, Charles Hulten, and Daniel Sichel, "Measuring Capital and Technology: An Expanded Framework." In Measuring Capital in the New Economy, C. Corrado, J. Haltiwanger, and D. Sichel, eds., Studies in Income and Wealth, Vol. 65. Chicago: The University of Chicago Press, 2005, 11-41.

Corrado, Carol, Charles Hulten, and Daniel Sichel, "Intangible Capital and Economic Growth," The Review of Income and Wealth, vol. 55 (3), 2009, 661-685.

Garvin, David A., and Lynne C. Levesque, "Meeting the Challenge of Corporate Entrepreneurship," Harvard Business Review, October 2006. 
Hall, Bronwyn H., "New Evidence on the Impacts of R\&D," Brookings Papers on Economic Activity, Microeconomics, 1993.

Hall, Robert E., "The Relation Between Price and Marginal Cost in U.S. Industry," Journal of Political Economy, 96, 1988, 921-947.

Hulten, Charles R., "Growth Accounting," National Bureau of Economic Research Working Paper 15341, September 2009.

Hulten, Charles R., and Xiaohui Hao, "What is a Company Really Worth? Intangible Capital and the "Market to Book Value" Puzzle," National Bureau of Economic Research Working Paper 14548, December 2008.

Hulten, Charles R. and Frank C. Wykoff, "The Estimation of Economic Depreciation Using Vintage Asset Prices," Journal of Econometrics, 15, 1981, 367-396.

Jones, Charles I., "R\&D-Based Models of Economic Growth," Journal of Political Economy, 103, No. 4, 1995, 759-784.

Jorgenson, Dale W. and Zvi Griliches, "The Explanation of Productivity Change," Review of Economic Studies, 34, July 1967, 34983.

Lev, Baruch, Intangibles: Management, Measurement, and Reporting, Brookings Institution Press, Washington D.C., 2001.

Mandel, Michael, "Why The Economy Is a Lot Stronger Than You Think," Business Week, February 13, 2006, 62-70.

Nakamura, Leonard, "Intangibles: What Put the New in the New Economy?" Federal Reserve Bank of Philadelphia Business Review, July/August 1999, 3-16.

Nakamura, Leonard, "What is the US Gross Investment in Intangibles? (At Least) One Trillion Dollars a Year!" Federal Reserve Bank of Philadelphia Working Paper No. 0115, 2001.

National Research Council, At What Price?: Conceptualizing and Measuring Cost-ofLiving and Prices Indexes, Panel on Conceptual, Measurement, and Other Statistical Issues in Developing Cost-of-Living Indexes, C. Schultze and C. Mackie, eds., Committee on National Statistics, Washington, D.C., National Academy Press, 2002.

Nordhaus, William D., "Do Real Output and Real Wage Measures Capture Reality? The History of Lighting Suggests Not," Timothy Bresnahan and Robert J. Gordon, eds., The Economics of New Goods, Studies in Income and Wealth, Volume 58, Chicago: University of Chicago Press for the National Bureau of Economic Research, 1997, 2966. 
Penrose, Edith T., The Theory of the Growth of the Firm, Basil Blackwell Mott, 1959.

Pindyck, Robert S., and Daniel L. Rubenfeld, Microeconomics, Pearson/Prentice Hall, New Jersey, 7ed., 2009.

Robbins, Carol A., and Carol E. Moylan, "Research and Development Satellite Account Update Estimates for 1959-2004 New Estimates for Industry, Regional, and International Accounts," Survey of Current Business, October 2007, 49-92.

Romer, Paul M., "Increasing Returns and Long-Run Growth," Journal of Political Economy, 94, No. $5,1986,1002-1037$.

Romer, Paul M., "Endogenous Technical Change," Journal of Political Economy, 98, No. 5, October, 1990, S71-S102.

Solow, Robert M., "Technical Change and the Aggregate Production Function," Review of Economics and Statistics, 39, August 1957, 312320.

Triplett, J., "Hedonic Functions and Hedonic Indexes," in John Eatwell, Murray Milgate and Peter Newman, eds., The New Palgrave Dictionary of Economics, Vol. 2, New York: The Macmillan Press Limited, 1987, 630-634.

U.S. Department of Labor, Bureau of Labor Statistics, Trends in Multifactor Productivity, 1948-81, Bulletin 2178, USGPO, Washington D.C., September 1983, and various updates and releases.

U.S. Department of Labor, Bureau of Labor Statistics, Bulletin 2331, The Impact of Research and Development on Productivity Growth, September 1989.

van Ark, Bart, Mary O'Mahony, and Marcel P. Timmer, "The Productivity Gap between Europe and the United States: Trends and Causes," Journal of Economic Perspectives, 22, 1, Winter 2008, 25-44.

Williamson, Oliver E., Markets and Hierarchies: Some Elementary Considerations, American Economic Review, 63, 2, May 1973, 316-325. 
TABLE 1

Annual Change in Labor Productivity, Nonfarm Business Sector BLS Estimates From CHS Table 7

\begin{tabular}{lcc|c}
\hline Average Annual Growth Rates & $\begin{array}{c}1973- \\
1995\end{array}$ & $\begin{array}{c}\text { 1995- } \\
\text { 2003 }\end{array}$ & $\begin{array}{c}\text { Memo: } \\
\text { Accel. }^{2}\end{array}$ \\
\hline 1. Labor productivity (percent) & 1 & 1.48 \\
Contribution of Components: $^{2}$ & 1.472 .95 & \\
2. Capital deepening & & .53 \\
3. IT equipment \& Software & .731 .26 & .53 \\
4. Other tangible capital & .46 .99 & .00 \\
5. Labor composition & .27 .27 & .10 \\
6. Multifactor productivity & .27 .37 & .85 \\
\hline
\end{tabular}

TABLE 2

BLS Estimates Augmented to Include Business Investment in Intangibles, From CHS Table 5

\begin{tabular}{ll|l}
\hline $\begin{array}{l}\text { 1. Labor productivity (percent) } \\
\text { Contribution of Components. }\end{array}{ }^{1}$ & 1.633 .09 & 1.45 \\
2. Capital deepening & .971 .68 & \\
3. Tangibles & .55 .85 & .71 \\
4. $\quad$ IT equipment & .30 .60 & .30 \\
5. $\quad$ Other $^{3}$ & .25 .24 & .30 \\
6. Intangibles & .43 .84 & -.01 \\
7. Software $\quad$ Other (new CHS) & .12 .27 & .41 \\
8. $\quad .31 .57$ & .15 \\
10. Labor composition & .25 .33 & .26 \\
11. Multifactor productivity & .411 .08 & .08 \\
\hline
\end{tabular}

1. Output per hour of all persons.

2. Percentage points. Components may not sum to totals because of independent rounding.

3. Includes mineral exploration and the architectural and design services embedded in equipment purchases that are part of " $\mathrm{CHS}$ intangibles included in the NIPAs" in tables 1 and 2.

Source: Corrado, Hulten, and Sichel (2009) 
Table 3

Data from Conventional Microsoft Income Statement Modified to Include Intangibles 2006 (\$billions)

\begin{tabular}{|l|r|r|r|r|}
\hline \multicolumn{1}{|c|}{ ITEM } & $\begin{array}{r}\text { STAN- } \\
\text { DARD }\end{array}$ & $\begin{array}{c}\text { PLUS } \\
\text { R\&D }\end{array}$ & $\begin{array}{c}\text { PLUS } \\
\text { S\&M }\end{array}$ & $\begin{array}{c}\text { PLUS } \\
\text { G\&A }\end{array}$ \\
\hline 1. Value of Product & $\$ 44$ & $\$ 55$ & $\$ 66$ & $\$ 67$ \\
\hline 2. Cost of Revenue & $\$ 8$ & $\$ 8$ & $\$ 8$ & $\$ 8$ \\
\hline 3. R \& D & $\$ 7$ & $\$ 7$ & $\$ 7$ & $\$ 7$ \\
\hline 4. Sales and Marketing & $\$ 10$ & $\$ 10$ & $\$ 10$ & $\$ 10$ \\
\hline 5. General \& Administration & $\$ 4$ & $\$ 4$ & $\$ 4$ & $\$ 4$ \\
\hline 6. Subtract Depreciation & $-\$ 1$ & $-\$ 1$ & $-\$ 1$ & $-\$ 1$ \\
\hline 7. Total Current Expenses & $\$ 27$ & $\$ 27$ & $\$ 27$ & $\$ 27$ \\
\hline 8. Operating Surplus & $\$ 18$ & $\$ 28$ & $\$ 39$ & $\$ 40$ \\
\hline 9. Depreciation (Total) & $\$ 1$ & $\$ 10$ & $\$ 19$ & $\$ 20$ \\
\hline 10. Gross Operating Income & $\$ 16$ & $\$ 18$ & $\$ 20$ & $\$ 20$ \\
\hline 11. Add in Other Income & $\$ 18$ & $\$ 20$ & $\$ 22$ & $\$ 22$ \\
\hline 12. Taxes & $\$ 6$ & $\$ 6$ & $\$ 6$ & $\$ 6$ \\
\hline 13. Net Income & $\$ 13$ & $\$ 14$ & $\$ 16$ & $\$ 17$ \\
\hline
\end{tabular}

Detail may not add due to rounding error. 
TABLE 4

2006 MICROSOFT BALANCE SHEET ITEMS

Revised to Include Capitalized Intangibles

2006 (\$billions)

\begin{tabular}{|c|c|c|c|c|c|}
\hline & & Standard & Add R\&D & Add S\&M & Add G\&A \\
\hline Plant \& Equipment & & $\$ 3$ & $\$ 3$ & $\$ 3$ & $\$ 3$ \\
\hline Intangibles Stocks & & $\$ 4$ & $\$ 40$ & $\$ 66$ & $\$ 70$ \\
\hline Total Equity & & $\$ 40$ & $\$ 75$ & $\$ 102$ & $\$ 106$ \\
\hline Total Assets & & $\$ 70$ & $\$ 105$ & $\$ 131$ & $\$ 136$ \\
\hline Equity Rate of Return & & $31.4 \%$ & $18.9 \%$ & $16.1 \%$ & $15.7 \%$ \\
\hline \multicolumn{6}{|l|}{ Percentage of Market } \\
\hline $\begin{array}{l}\text { Capitalization Explained } \\
\text { By Shareholder Equity }\end{array}$ & & $17 \%$ & $32 \%$ & $43 \%$ & $45 \%$ \\
\hline \multicolumn{6}{|c|}{ Memo: Own-Intangible Stock Detail } \\
\hline R\&D Stock & $\$ 35$ & & & & \\
\hline S\&M Stock & $\$ 27$ & & & & \\
\hline G\&A Stock & $\$ 5$ & & & & \\
\hline Total & $\$ 66$ & & & & \\
\hline
\end{tabular}




\section{TABLE 5}

\section{COMPONENTS OF MICROSOFT'S TOTAL OUTPUT}

Constant (2000) Dollar Output, Prices, and Value Shares

(Average Annual Growth Rates and Percentage Shares)

\begin{tabular}{|c|c|c|c|c|}
\hline 1. OUTPUT QUANTITIES (AAGR) & 1988-1994 & $1995-2000$ & $2001-2006$ & 1988-2006 \\
\hline Direct Product & $49.6 \%$ & $31.9 \%$ & \multicolumn{2}{|c|}{$14.4 \% 32.9 \%$} \\
\hline Research and Development & $39.0 \%$ & $35.2 \%$ & \multicolumn{2}{|c|}{$6.1 \% 27.4 \%$} \\
\hline Sales and Marketing & $36.9 \%$ & $18.8 \%$ & \multicolumn{2}{|c|}{$9.9 \% 22.6 \%$} \\
\hline General and Administrative & $19.7 \%$ & $29.3 \%$ & \multicolumn{2}{|c|}{$13.2 \% 27.7 \%$} \\
\hline Quantity of Total Output & $45.3 \%$ & $30.0 \%$ & $12.2 \%$ & $30.0 \%$ \\
\hline 2. OUTPUT SHARES (\%) & $1988-1994$ & $1995-2000$ & $2001-2006$ & $1988-2006$ \\
\hline Product & $65.8 \%$ & $64.1 \%$ & \multicolumn{2}{|c|}{$65.0 \% 65.0 \%$} \\
\hline Research and Development & $13.2 \%$ & 17.7 & \multicolumn{2}{|c|}{$18.2 \% 16.2 \%$} \\
\hline Sales and Marketing & $20.2 \%$ & $17.2 \%$ & \multicolumn{2}{|c|}{$15.1 \% 17.6 \%$} \\
\hline General and Administrative & $0.9 \%$ & $1.0 \%$ & \multicolumn{2}{|c|}{$1.7 \% 1.2 \%$} \\
\hline Total & $100.0 \%$ & $100.0 \%$ & $100.0 \%$ & $100.0 \%$ \\
\hline 3. OUTPUT PRICES (AAGR) & 1988-1994 & $1995-2000$ & 2001-2006 & $1988-2006$ \\
\hline Product & $-12.5 \%$ & $-5.2 \%$ & $-3.5 \%$ & $-7.3 \%$ \\
\hline Research and Development & $1.0 \%$ & $-1.7 \%$ & $0.1 \%$ & $-0.1 \%$ \\
\hline Sales and Marketing & $3.4 \%$ & $2.6 \%$ & $1.4 \%$ & $2.5 \%$ \\
\hline General and Administrative & $3.8 \%$ & $3.1 \%$ & $4.9 \%$ & $3.9 \%$ \\
\hline Output Price & $-7.4 \%$ & $-3.1 \%$ & $-2.0 \%$ & $-4.4 \%$ \\
\hline
\end{tabular}

Sources: Financial statements, and externally derived price deflators (see text). Detail may not add due to rounding error 


\section{TABLE 6}

\section{THE SOURCES OF GROWTH OF THE MICROSOFT CORPORATION (average annual growth rates)}

\begin{tabular}{|c|c|c|c|c|}
\hline & 1988-1994 & $1995-2000$ & 2001-2006 & 1988-2006 \\
\hline Total Real Output (Q) & \multicolumn{3}{|c|}{$45.3 \% 30.0 \% 12.2 \%$} & $30.0 \%$ \\
\hline Labor Input $(L)^{*}$ & \multicolumn{3}{|c|}{$5.1 \% \quad 2.1 \% 1.5 \% 3.0 \%$} & \\
\hline Intermediate Input (M)* & \multicolumn{3}{|c|}{$8.8 \% 4.7 \% 2.6 \%$} & $5.5 \%$ \\
\hline Tangible Capital Input (K)* & $3.8 \%$ & $1.6 \%$ & $0.5 \%$ & $2.1 \%$ \\
\hline Intangible Capital Input (R)* & $16.9 \%$ & $15.5 \%$ & $6.9 \%$ & $13.3 \%$ \\
\hline Total Factor Productivity (TFP) & \multicolumn{3}{|c|}{$10.9 \% 6.1 \% 0.8 \%$} & $6.2 \%$ \\
\hline Tangible Capital Detail & -1994 & $1995-2000$ & 2001-2006 & 1988-2006 \\
\hline Land** & \multicolumn{2}{|c|}{$0.5 \% 0.0 \% 0.0 \%$} & & $0.2 \%$ \\
\hline Buildings ${ }^{* *}$ & \multicolumn{2}{|c|}{$1.4 \% 0.5 \% 0.1 \%$} & & $0.7 \%$ \\
\hline IT Equipment** & \multicolumn{2}{|c|}{$1.3 \% 0.9 \% 0.3 \%$} & & $0.8 \%$ \\
\hline Non-IT Equipment** & \multicolumn{2}{|c|}{$0.6 \% 0.2 \% 0.1 \%$} & & $0.3 \%$ \\
\hline Total Tangibles & \multicolumn{2}{|c|}{$3.8 \% 1.6 \% 0.5 \%$} & & $2.1 \%$ \\
\hline Intangible Capital Detail & -1994 & $1995-2000$ & $2001-2006$ & 1988-2006 \\
\hline Research \& Development*** & $6.6 \%$ & $9.2 \%$ & $3.9 \%$ & $6.6 \%$ \\
\hline Sales and Marketing ${ }^{* * *}$ & \multicolumn{2}{|c|}{$9.9 \% 5.8 \% 2.6 \%$} & & $6.3 \%$ \\
\hline General \& Administration ${ }^{* * *}$ & $0.3 \%$ & $0.4 \%$ & $0.4 \%$ & $0.4 \%$ \\
\hline Total Intangibles & $16.9 \%$ & $15.5 \%$ & $6.9 \%$ & $13.3 \%$ \\
\hline
\end{tabular}

Source: Author's calculations.

* Weighted by share in total value of product

** Weighted by relative share in total value of tangible capital income

*** Weighted by relative share in total value of intangible capital income 


\section{TABLE 6 (Addendum)}

\section{Real Output and Components of Input Growth (Average Annual Growth Rates and Percentage Shares)_}

\begin{tabular}{|c|c|c|c|c|}
\hline 1. UNWEIGHTED AAGR & 1988-1994 & $1995-2000$ & 2001-2006 & $1988-2006$ \\
\hline Total Real Output (Q) & $45.3 \%$ & $30.0 \%$ & $12.2 \%$ & $30.0 \%$ \\
\hline Labor Input (L) & $30.4 \%$ & $15.7 \%$ & $9.9 \%$ & $19.3 \%$ \\
\hline Intermediate Input (M) & $35.1 \%$ & $22.1 \%$ & $11.7 \%$ & $23.6 \%$ \\
\hline Tangible Capital Input (K) & $23.6 \%$ & $17.9 \%$ & $9.1 \%$ & $17.2 \%$ \\
\hline Intangible Capital Input (R) & $40.2 \%$ & $27.5 \%$ & $12.3 \%$ & $27.4 \%$ \\
\hline \multicolumn{5}{|l|}{ 2. AAGR OF RATIOS } \\
\hline$Q / L$ & $14.9 \%$ & $14.3 \%$ & $2.3 \%$ & $10.8 \%$ \\
\hline$M / L$ & $4.7 \%$ & $6.4 \%$ & $1.8 \%$ & $4.3 \%$ \\
\hline $\mathrm{K} / \mathrm{L}$ & $-6.8 \%$ & $2.2 \%$ & $-0.9 \%$ & $-2.1 \%$ \\
\hline $\mathrm{R} / \mathrm{L}$ & $9.8 \%$ & $11.8 \%$ & $2.3 \%$ & $8.1 \%$ \\
\hline 3. FACTOR SHARES: & 1988-1994 & $1995-2000$ & $2001-2006$ & $1988-2006$ \\
\hline Labor Input Share & $16.5 \%$ & $13.8 \%$ & $15.9 \%$ & $15.5 \%$ \\
\hline Intermediate Share & $24.8 \%$ & $20.7 \%$ & $23.9 \%$ & $23.2 \%$ \\
\hline Tangible Capital Share & $16.1 \%$ & $9.0 \%$ & $4.9 \%$ & $10.3 \%$ \\
\hline Intangible Capital Share & $42.7 \%$ & $56.5 \%$ & $55.4 \%$ & $51.0 \%$ \\
\hline
\end{tabular}

Sources: Author's calculations, based on financial statements, and externally derived price deflators. Detail may not add due to rounding error 


\section{TABLE 7}

The Sources of Growth of Microsoft

With and Without Adjustment For Product Quality Change

(Average Annual Growth Rates)

\begin{tabular}{lrrrr}
\hline & & & & \\
& $1988-1994$ & $1995-2000$ & $2001-2006$ & $1988-2006$ \\
& $-12.5 \%$ & $-5.2 \%$ & $-3.5 \%$ & $-7.3 \%$ \\
Product Price & $0.0 \%$ & $0.0 \%$ & $0.0 \%$ & $0.0 \%$ \\
Product Price (NQC) & & & & \\
Total Output Price & $-7.4 \%$ & $-3.1 \%$ & $-2.0 \%$ & $-4.4 \%$ \\
Total Output Price (NQC) 0.8\% & & $0.2 \%$ & $0.3 \%$ & $0.4 \%$ \\
& & & & \\
Total Output Quantity & $45.4 \%$ & $30.0 \%$ & $12.2 \%$ & $30.0 \%$ \\
Total Output Quantity (NQC) $37.1 \%$ & & $26.7 \%$ & $10.0 \%$ & $25.2 \%$ \\
& $10.9 \%$ & $6.1 \%$ & $0.8 \%$ & $6.2 \%$ \\
TFP & $2.6 \%$ & $2.7 \%$ & $-1.5 \%$ & $1.4 \%$ \\
TFP (NQC) & $8.3 \%$ & $3.3 \%$ & $2.3 \%$ & $4.8 \%$ \\
Quality Effect & & & & \\
\hline
\end{tabular}

Source: Author's calculations. Detail may not add due to rounding error.

*NQC is "no quality change"

TABLE 8

Sources of Growth of

Real Value Added per Worker

Comparison of Microsoft and Non-farm Business Sector

Average Annual Growth Rates, 1995-2003

\begin{tabular}{|l|c|c|c|}
\hline & & Microsoft & $\begin{array}{c}\text { CHS } \\
\text { Non-farm Busin. }\end{array}$ \\
\hline Real Value Added per Worker & & $10.00 \%$ & $3.09 \%$ \\
\hline Tangible Capital per Worker & & $0.19 \%$ & $0.85 \%$ \\
\hline Software Capital per Worker & & N/A & $0.27 \%$ \\
\hline Intangible Capital per Worker & & $6.30 \%$ & $0.57 \%$ \\
\hline TFP + Labor Composition & & $3.51 \%$ & $1.41 \%$ \\
\hline
\end{tabular}




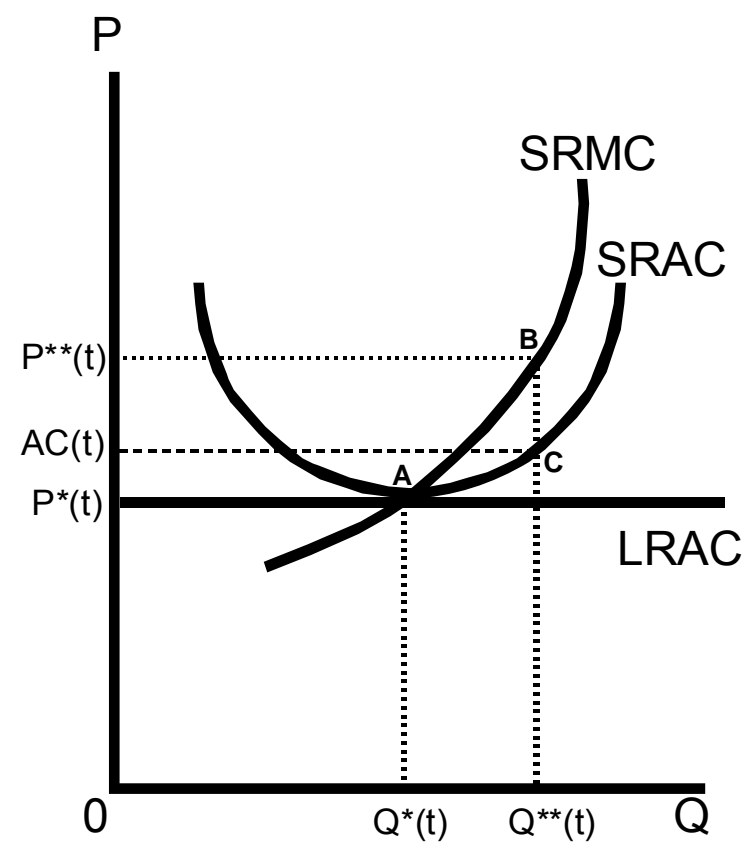

FIGURE 1

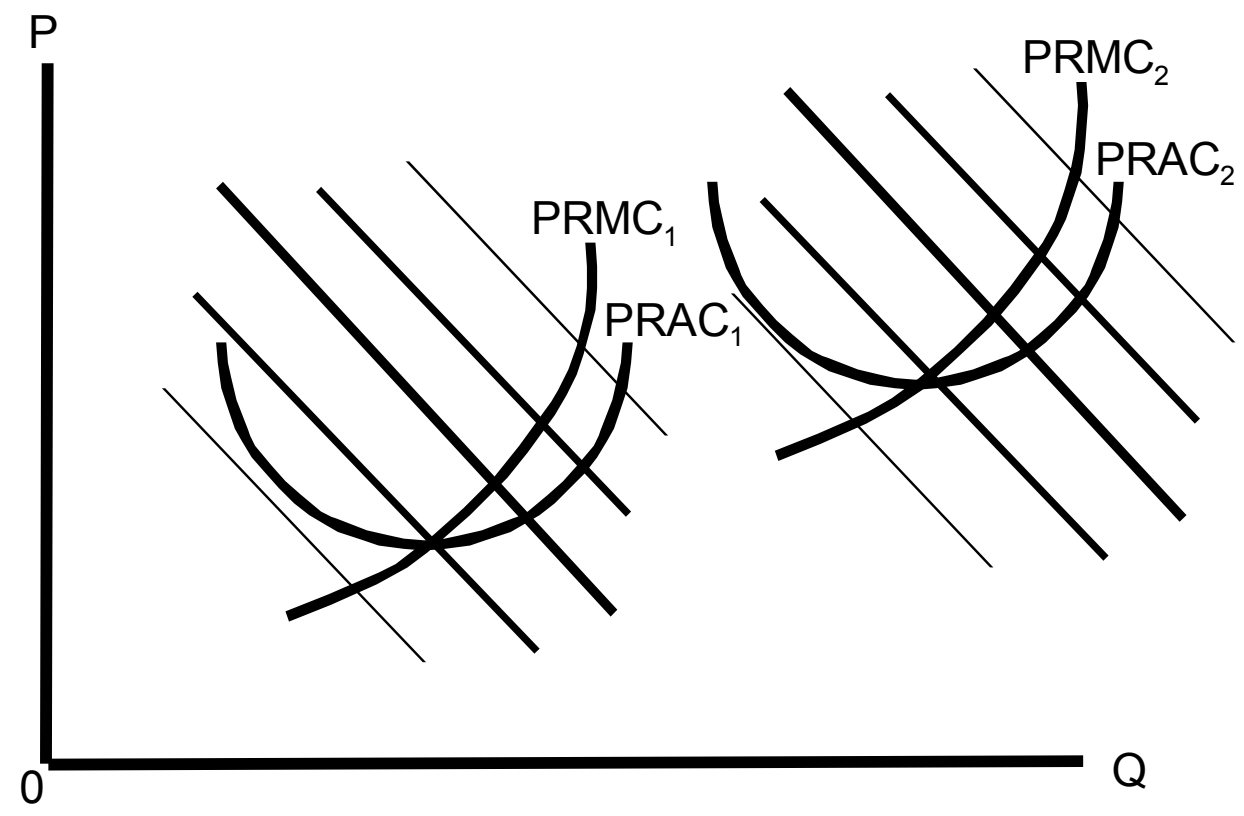

FIGURE 2 